LEADING ARTICLE

\title{
Edward P. Abraham, Cell-free Systems and the Fungal
}

\section{Biosynthesis of Beta-lactams}

\author{
ARNOLD L. DEMAIN \\ Biology Department, Massachusetts Institute of Technology, \\ Cambridge, MA 02139, U.S.A.
}

(Received for publication July 24, 2000)

\begin{abstract}
"The development of the $\beta$-lactam antibiotics could not have been envisaged by

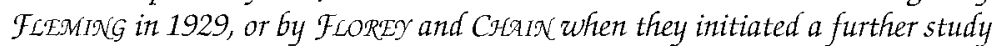
of penicillin 10 years later Even in 1940 F LEMING wrote, "Penicillin has not yet been tried in war surgery and it will not be tried until some chemist comes along and finds out what it is and if possible manufactures it." In the event it was the microbiologists who were largely responsible for transforming what at that time seemed to be an almost impossible project, the economic production of penicillin by fermentation on a large scale."
\end{abstract}

Sir EDWARD ABRAHAM, 1983

Today much is known about the biology of penicillin and cephalosporin production by fungi including the pathways, the biosynthetic enzymes including some crystal structures, the genes and their cloning, expression, sequencing and chromosomal locations, the regulation of the genes and enzymes and even some intelligent guesses about their evolutionary relationships. The key breakthrough that led to rapid progress in these areas was the subcellular work done by EDWARD P. ABRAHAM and his Oxford colleagues in the early 1970s. With his advice and encouragement, my laboratory was able to prepare reliably active soluble cell-free preparations which were instrumental in elucidation of the biosynthetic pathways in fungi (and also in bacteria) by laboratories throughout the world.

I began my studies on penicillin biosynthesis at the Merck penicillin factory in central Pennsylvania in 1954. Tracer work had just been published on the incorporation of the entire L-cysteine molecule and the carbon skeleton of valine into the hydrophobic penicillin $\mathrm{G}^{1,2)}$. Furthermore, the sidechain was found to be formed from phenylacetate ${ }^{3)}$. Using washed and starved resting cells, I was able to show that cystine stimulated and $S$-ethyl-DL-cysteine and $\alpha$ methyl-DL-valine inhibited penicillin $G$ production by Penicillium chrysogenum and that these inhibitions could be reversed by L-cystine and DL-valine respectively ${ }^{4}$. Furthermore, D-valine was shown to be an inhibitor of penicillin synthesis while L-valine stimulated, suggesting that the precursor of the D-valine moiety was L-valine.
I next tested the effect of all the other protein amino acids on synthesis by starved resting cells and made the unexpected observation that L-lysine was inhibitory ${ }^{5}$. The results appeared to explain previous results by BONNER ${ }^{6}$ ) who found lysine auxotrophs to be poor penicillin producers; the added lysine (required for growth) apparently inhibited the process. The significance of the lysine effect was unknown. Also unknown was the mechanism by which cysteine and valine condensed in forming the penicillin nucleus or the stage at which phenylacetate was incorporated as sidechain. Of interest here was the discovery by $\mathrm{KATO}^{7)}$ of an unknown compound (thought to be the "penicillin nucleus") only in fermentations conducted in the absence of the sidechain 
precursor, phenylacetate. In 1955, I was able to confirm the production of "KATO's compound" cited in DEMAIN" which was later identified as 6-aminopenicillanic acid $(6 \mathrm{APA})^{9)}$. Little did we know at that time that the lysine effect was related to sidechain attachment. However, we soon found out that lysine inhibition of penicillin synthesis by resting cells could be reversed by $\alpha$-aminoadipate and that $\alpha$-aminoadipate also stimulated penicillin formation in the absence of added lysine ${ }^{10)}$. We concluded that the relative concentration of lysine and $\alpha$-aminoadipate is crucial to penicillin formation, that $\alpha$-aminoadipate has a role in penicillin synthesis, and that lysine interferes with that role. The role became clearer when the report of ARNSTEIN $^{11)}$ was considered. These workers had found that $\delta$-( $\alpha$-aminoadipyl)cysteinylvaline (ACV) was formed intracellularly during penicillin $G$ biosynthesis. They speculated that ACV is cyclized to a penicillin containing an $\alpha$-aminoadipate sidechain which would then exchange this sidechain with phenylacetate to produce penicillin $G$. Of great interest in this regard was the isolation by FLYNN $^{12)}$ from mycelium of $P$. chysogenum of a hydrophilic penicillin containing an L- $\alpha$-aminoadipate sidechain, which was named isopenicillin $N$. It thus appeared probable $^{13)}$ that isopenicillin $\mathrm{N}$ was the intermediate which exchanges its sidechain with phenylacetate to generate penicillin G. Since L- $\alpha$-aminoadipate was known to be an intermediate in L-lysine biosynthesis in fungi, we further hypothesized that L-lysine was causing a negative feedback effect early in its own biosynthesis, thus limiting formation of $\mathrm{L}-\alpha$-aminoadipate which in turn would decrease formation of $\mathrm{ACV}$ and penicillin $\mathrm{G}^{10}$.

The above concepts dealing with lysine inhibition were proven correct by later work done at M.I.T. in the early 1970 's by my student, Prakash Masurekar, and my postdoctoral associate, CORNELIUS FRIEDRICH. We showed that feedback inhibition was the main mechanism of lysine control $^{14)}$. We further demonstrated that an early-blocked lysine bradytroph (=leaky auxotroph) which excreted homocitrate (the first compound on the lysine biosynthetic pathway) was feedback inhibited in homocitrate formation by addition of L-lysine ${ }^{15)}$. Accordingly, lysine regulatory mutants of $P$. chrysogenum which overproduced lysine, were found to be poor producers of penicillin ${ }^{16)}$. Although homocitrate synthase in extracts was insensitive to lysine presumably due to desensitization during preparation ${ }^{17)}$, the site of in vivo lysine action was shown to be homocitrate synthase by the fact that lysine inhibition of starved resting cells was reversed by homocitrate as well as by the later members of the pathway, i.e., $\alpha$-ketoadipate and $\alpha$ aminoadipate $^{18)}$. We also found that the rate of penicillin formation correlated directly with the intracellular concentration of $\alpha$-aminoadipate ${ }^{19)}$.

A major breakthrough in $\beta$-lactam biosynthesis was provided by the discoveries made by EDWARD ABRAHAM on hydrophilic $\beta$-lactams in the $1950 \mathrm{~s}$ and $1960 \mathrm{~s}$. GOTTSHALL ${ }^{20)}$ had discovered "synnematin B" in broths from Cephalosporium salmosynematum and CRAWFORD ${ }^{21)}$ reported on the production of "cephalosporin N" by Cephalosporium sp. ABRAHAM ${ }^{22)}$ found the compounds to be an identical penicillin possessing the hydrophilic D- $\alpha$-aminoadipate sidechain. (Although the name "cephalosporin N" persisted for a few years, it was later more properly named penicillin N.) In 1955, a momentous discovery was made in the Abraham laboratory, i.e., the isolation and identification of cephalosporin $\mathrm{C}$ from the penicillin N-producing Cephalosporium sp. culture ${ }^{23)}$. Not only was cephalosporin $\mathrm{C}$ of intense interest because of its resistance to staphylococcal penicillinase, it also represented the first naturally-occuring $\beta$-lactam antibiotic without a 6APA nucleus, possessing instead the 7aminocephalosporanic acid nucleus ${ }^{24)}$. The culture also produced a steroidal antibiotic called "cephalosporin $\mathrm{P}$ "25). It was of interest that both penicillin $\mathrm{N}$ and cephalosporin $\mathrm{C}$ from Cephalosporium contained a D- $\alpha$-aminoadipate sidechain whereas the isopenicillin $\mathrm{N}$ from $P$. chrysogenum contained an $\mathrm{L}-\alpha$-aminoadipate sidechain.

With regard to the biosynthetic pathway to cephalosporin $\mathrm{C}$ in Cephalosporium acremonium (known at various times as Cephalosporum sp., Acremonium strictum and, most recently, Acremonium chrysogenum), ABRAHAM's group showed that the acetoxy group is derived from acetate ${ }^{26)}$ and cysteine is incorporated intact into the $\beta$-lactam ring ${ }^{27)}$. The sites of incorporation were the thiazolidine ring for valine and the sidechain for aminoadipate ${ }^{26,27)}$.

It was clear in the early 1970s that studies with intact cells had revealed the precursors of $\beta$-lactams but firm knowledge of the pathway and the enzymes involved was not at hand. What was needed was a new breakthrough involving cell-free systems and this was again provided by EDWARD ABraham. At a symposium on antibiotics taking place in St. Marguerite in the Canadian Laurentians in early 1971, ABRAHAM announced that he and BronwELl LODER had converted labelled phenylacetate plus coenzyme $\mathrm{A}$ and either 6APA or isopenicillin $\mathrm{N}$ to labelled penicillin using a broken cell system from $P$. chrysogenum ${ }^{28)}$. He concluded that the reactions occurred in the following order: isopenicillin $\mathrm{N} \rightarrow$ penicillin $\mathrm{G} \leftrightarrow 6 \mathrm{APA}$. Also in that year, they ${ }^{29)}$ had isolated three peptides from mycelium of $C$. acremonium, one of which was $\delta$-(L- $\alpha$-aminoadipyl)-Lcysteinyl-D-valine (LLD-ACV). They postulated that 
isopenicillin $\mathrm{N}$ was a precursor of penicillin $\mathrm{N}$ and cephalosporin C. ABRAHAM also reported that a broken cell system from $C$. acremonium could convert labelled valine plus $\delta$-(L- $\alpha$-aminoadipyl)-L-cysteine (LL-AC) to LLD$\mathrm{ACV}$, the activity being particulate in nature and not in the supernatant fluid. The presence of dipeptide LL-AC was essential for this reaction ${ }^{30}$; no labelled antibiotic was formed however. I had attended this lecture, and after returning from Canada, I wrote АвRAнам and asked him to provide details on the preparation of the broken cell systems from $P$. chrysogenum and $C$. acremonium. On April 28, he and LODER kindly replied that the former was prepared by grinding with sand and the latter by ultrasonication, centrifugation and harvesting the particulate material.

The ability to produce tripeptide but not antibiotic from dipeptide plus valine using broken cells of $C$. acremonium $^{31,32)}$ suggested to us that the enzymatic system responsible for the biosynthesis of $\beta$-lactam antibiotics was part of an unstable complex, and that the structure of this complex was destroyed by drastic treatments. In an earlier paper, ABRAHAM ${ }^{33)}$ had suggested that the conversion of cells into protoplasts followed by gentle lysis might preserve the integrity of the biosynthetic system. In preliminary work, DUNCAN and NEWTON ${ }^{34)}$ observed the incorporation of labelled $\mathrm{L}$-valine into penicillin $\mathrm{N}$ by a sonicated protoplast preparation from $C$. acremonium. Furthermore, lyzed protoplasts could convert labelled valine in the presence of $\delta$-(L- $\alpha$-aminoadipyl)-L-cysteine, ATP and an energy-generating system into a penicillin; it also converted labelled LLD-ACV into penicillin $\mathrm{N}^{32}$. In a letter to me dated December 17, 1973, ABRAHAM stated that his lyzed protoplast-derived cell-free systems "may not be generally applicable, however, because we were only successful with one out of three other strains of $P$. chrysogenum". He further wrote that the yields of penicillin $\mathrm{N}$ produced from labelled valine by lyzed protoplasts of $C$. acremonium "are very low... We badly need to increase the efficiency of this system and if we are successful I shall let you know. But until it has been improved I should have great hesitation in recommending it to you as a going concern."

Despite ABRAHAM's reservations, we thought the protoplast lysate approach was very promising ${ }^{35)}$ and that confirmation of the activity of the system was important. We prepared protoplasts of $C$. acremonium with enzyme preparations from either Helix pomatia (snail) digestive juice or Cytophaga. Protoplast yield depended on the enzyme used, the age of the culture and increased if the mycelium was pretreated with dithiothreitol. The cell-free preparation, obtained by osmotic lysis of the protoplasts, synthesized labelled penicillin $\mathrm{N}$ from labeled valine but did not form cephalosporin $\mathrm{C}$ nor its precursors, deacetylcephalosporin $\mathrm{C}$ and deacetoxycephalosporin $\mathrm{C}$. We had thus confirmed the cell-free studies of the Abraham laboratory. We next attempted to detect the synthesis of antibiotics by microbiological assay, rather than by using labelled precursor. We found that protoplast lysates yielded activity against a $\beta$-lactam-supersensitive mutant of Escherichia coli when incubated with an energy-generating system, mannitol, $\mathrm{MgSO}_{4}, \mathrm{KCl}$ and Tris-buffer in short time experiments (up to 5 hours) ${ }^{36)}$. The system was insensitive to Millipore filtration or cycloheximide and the product was a cephalosporin. The reaction was markedly stimulated by the addition of penicillin $\mathrm{N}$ but not by penicillin $\mathrm{G}$ or $6 \mathrm{APA}$. This strongly indicated that penicillin $\mathrm{N}$ was being converted to a cephalosporin, the first time that biological ring expansion of a penicillin had been observed. Up until this time, penicillin $\mathrm{N}$ and cephalosporin $\mathrm{C}$ had been generally considered to be end products of a branched pathway in C. acremonium. Here it was demonstrated that penicillin $\mathrm{N}$ was a precursor of a cephalosporin. We went on to show ${ }^{37)}$ that the product made from penicillin $\mathrm{N}$ was deacetoxycephalosporin $\mathrm{C}$ (DOAC). Mutants blocked early in biosynthesis, which made no antibiotic in fermentations, were able to carry out cell-free ring expansion. Later blocked mutants, which produced penicillin $\mathrm{N}$ but not cephalosporin $\mathrm{C}$ in fermentation, were incapable of cell-free ring expansion and were presumably blocked in the deacetoxycephalosporin $\mathrm{C}$ synthase reaction. We gave the trival name "expandase" to this enzyme.

At this point, we were concerned that in both our laboratory $^{35}$ and that of ABRAHAM ${ }^{32,34,38)}$, lyzed $C$. acremonium protoplasts converted labelled valine into what was thought to be penicillin $\mathrm{N}$ but not into a cephalosporin. If it truly was penicillin $\mathrm{N}$, why was it not converted into DOAC? We approached this problem by postulating that the product was not penicillin $\mathrm{N}$ but isopenicillin $\mathrm{N}$, which had previously been detected only in P. chrysogenum. TosHio KONOMI, a visiting scientist from Japan in my laboratory, added LLD-ACV to our C. acremonium cell-free extracts and examined the antibacterial spectrum of the penicillinase-labile product. He had previously determined that penicillin $\mathrm{N}$ inhibited the growth of Salmonella typhimurium ATCC 13311 and Pseudomonas aeruginosa Pss but not that of Staphylococcus aureus ATCC 25923 or Sarcina lutea ATTC 9341, whereas isopenicillin N had the opposite pattern. We found the reaction product to have the antibacterial spectrum of isopenicillin $\mathrm{N}$. At this time, we were preparing to present this exciting result at an 
Fig. 1. Conference on "Mechanisms of Beta-Lactam Biosynthesis" organized by Professor DAVID PERLMAN (front row, extreme left) at the School of Pharmacy of the University of Wisconsin on December 15, 1978.

Sir Edward Abraham is in front row center and the author is seated next to him (third from the right).

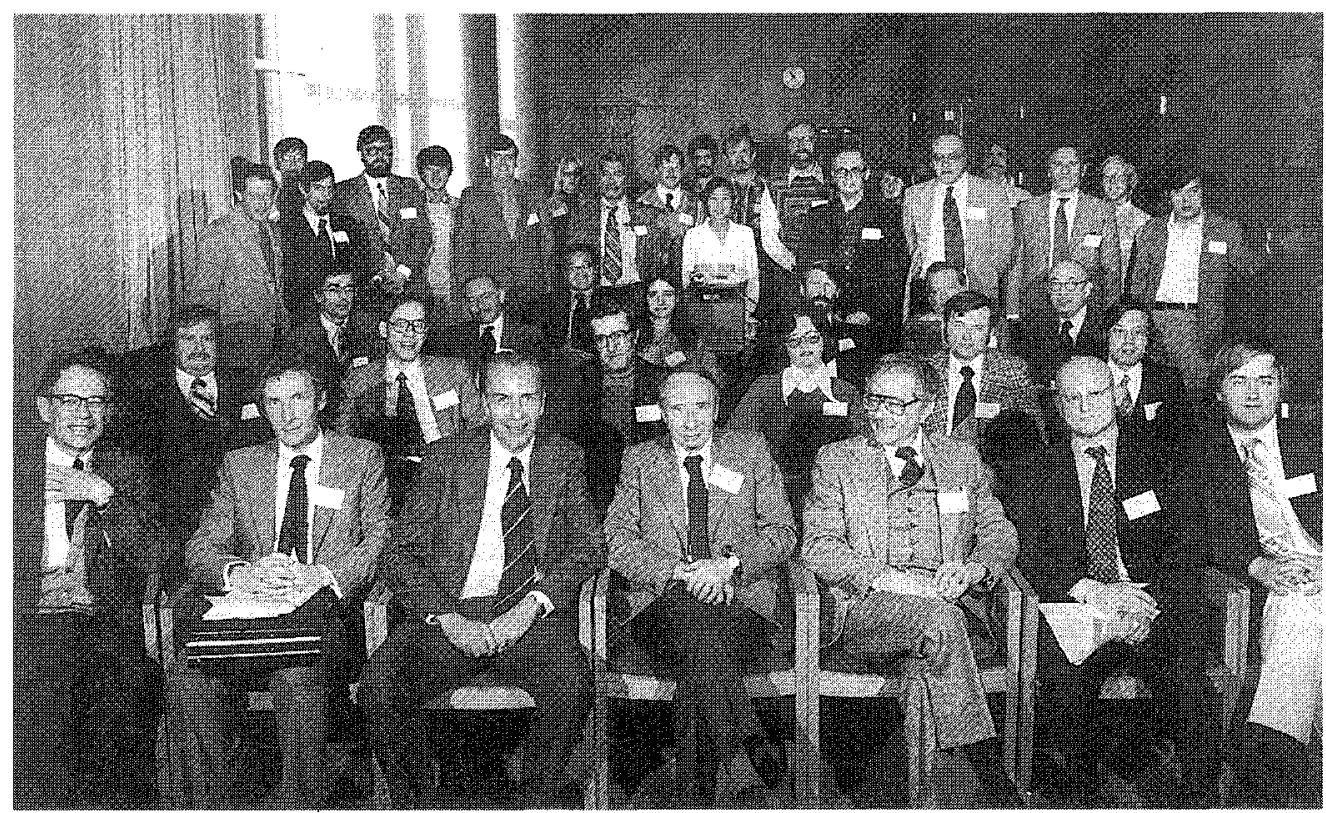

upcoming one day international symposium organized by Professor David Perlman at the University of Wisconsin in honor of the cell-free breakthrough in $\beta$-lactam biosynthesis. We headed to Madison, Wisconsin, laden with our bioassay plates to demonstrate our discovery. Fig. 1 shows the distinguished international group gathered for the symposium. Professor Abraham was given the initial spot on the program and I was to follow. I was shocked to hear him announce that O'SULLIVAN and he had made the same discovery by chemical detection of isopenicillin N. In discussing the findings of both laboratories with ABRAHAM after the meeting, he generously proposed that they delay publication of their paper until we prepared our manuscript. As a result, both papers ${ }^{39,40)}$ appeared back-to-back in the same issue of the Biochemical Journal.

Cell-free extracts were also crucial in defining the role of 6APA, or lack of one, in penicillin $G$ biosynthesis. Although 6APA accumulated in $P$. chrysogenum broths to which no sidechain precursor had been added, we doubted that free 6APA had a role in de novo biosynthesis of penicillin $\mathrm{G}^{41)}$. We felt that it was merely a shunt metabolite derived by deacylation of isopenicillin $\mathrm{N}$ in the absence of phenylacetate addition. Cell-free studies had indicated that the terminal reaction of penicillin $G$ biosynthesis was an exchange of the $\mathrm{L}-\alpha$-aminoadipate sidechain of isopenicillin $\mathrm{N}$ for phenylacetate from phenylacetylcoenzyme A. Such acyltransferase activity had been found in crude extracts and phenylacetyl-CoA had been shown to arise from phenylacetate and coenzyme $A$ by the action of a sidechain activating enzyme. The appearance of the enzyme preceded rapid penicillin $\mathrm{G}$ formation and declined at the same time as the penicillin $G$ production rate in fermentations. In the absence of phenylacetyl-CoA, isopenicillin $\mathrm{N}$ was hydrolyzed to 6APA by penicillin acyltransferase ${ }^{42)}$. This free 6APA may be converted later to penicillin $\mathrm{G}$ if phenylacetyl-CoA becomes available. This reasoning implicated isopenicillin $\mathrm{N}$ as the true immediate precursor of penicillin $\mathrm{G}$ and 6APA acylation as a salvage pathway. The observation in the Abraham laboratory ${ }^{43)}$ that extracts could convert isopenicillin $\mathrm{N}$, but not penicillin $\mathrm{N}$, to penicillin $\mathrm{G}$ was consistent with the above concept.

Rapid progress was made following the cell-free discoveries described above. The ring expansion of penicillin $\mathrm{N}$ to DOAC was improved markedly by the work of HoOK $^{44)}$, our own later studies ${ }^{45,46)}$ and those of FELIX ${ }^{47)}$, which showed the importance of ascorbate, $\alpha$-ketoglutarate 
and iron for this dioxygenase reaction. The preceeding reaction, the cyclization of LLD-ACV to isopenicillin $\mathrm{N}$ (to which we gave the trivial name "cyclase", otherwise known as isopenicillin $\mathrm{N}$ synthase or IPNS), was found to be stimulated by ferrous ions ${ }^{48)}$. For preparing cell-free extracts containing active cyclase and expandase, the laborious protoplast formation and lysis procedure was replaced by simple sonic oscillation.

The question still remained as to why the cell-free $C$. acremonium preparations converted LLD-ACV or valine into isopenicillin $\mathrm{N}$ but not into penicillin $\mathrm{N}$ and cephalosporins. The answer was provided by KonOMt ${ }^{40)}$ who showed that fresh cell-free extracts could convert LLD-ACV to a cephalosporin but frozen and thawed extracts could not, the reaction sequence stopping at isopenicillin N. Thus an extremely labile epimerase [called "racemase" by KONOMI ${ }^{40)}$ ] existed which could convert isopenicillin $\mathrm{N}$ to penicillin $\mathrm{N}$, thus changing the configuration of the $\alpha$-aminoadipyl sidechain from $\mathrm{L}$ to $\mathrm{D}$. The existence of this epimerase and its extreme lability were later confirmed in Oxford ${ }^{49,50)}$

It is quite remarkable that within two years of the KONOMI's ${ }^{40)}$ paper, a scheme of penicillin and cephalosporin biosynthesis, including the steps of cephamycin synthesis by actinomycetes, could be presented ${ }^{51)}$ and remains essentially correct today. The further hydroxylation of DAOC to deacetylcephalosporin $\mathrm{C}$ was shown to be catalyzed by cell-free extracts containing another $\alpha$ ketoglutarate-linked dioxygenase ${ }^{52-54)}$. The conversion of deacetylcephalosporin $\mathrm{C}$ to cephalosporin $\mathrm{C}$ was found to be carried out by the enzyme acetyl CoA deacetylcephalosporin $C$ acetyltransferase ${ }^{52,55)}$.

Once the active cell-free preparations were available, purification of the cyclase, epimerase and expandase proceeded in our laboratory ${ }^{46,56)}$ and in other ${ }^{57 \sim 59)}$. However, up until the mid-1980s, the reaction(s) leading to LLD-ACV was still unknown. It appeared the dipeptide LL-AC must be involved because of the early finding by ${ }^{30)}$ that broken cells could incorporate ${ }^{14} \mathrm{C}$-DL-valine into LLD-ACV but only when LL-AC was added. Geralid BANKO in my laboratory spent a full year trying to demonstrate the production of LL-AC from $L-\alpha-$ aminoadipate plus L-cysteine by cell-free extracts of $C$. acremonium but without success until he used $50 \%$ glycerol during sonication of the cells. With this modification, he was able to carry out a linear synthesis of LL-AC from its constituent amino acids for at least 6 hours, the reaction being dependent upon ATP and $\mathrm{Mn}^{2+}$ or $\mathrm{Mg}^{2+}{ }^{200}$. Obviously we were dealing with a very labile enzyme activity. Although at that time, we thought LL-AC to be a free intermediate, we later found that it was really an enzyme-bound intermediate of the ACV synthetase reaction $^{61)}$. We reasoned that if two enzymes were required for LLD-ACV synthesis from the component amino acids and the first exhibited inhibition by its product, LLD-ACV formation via the reaction LL-AC + L-valine would be faster than LL-AC formation from $\mathrm{L}-\alpha$-aminoadipate $+\mathrm{L}$ cysteine. We found this to be the case; however we unexpectedly observed that the conversion of the three amino acids to LLD-ACV was far more rapid than either of the two half reactions. We thus concluded that our cell-free preparation contained a single enzyme (which we designated ACV synthetase) which required the simultaneous binding of all three amino acids for maximum activity. We were able to support this conclusion by purification of ACV synthetase from C. acremonium $^{62}$. A summary of this work on ACV synthetase has been published ${ }^{631}$ as well as the use of this enzyme as a model system for enzymatic peptide synthesis ${ }^{64)}$.

Today, much is known about $\beta$-lactam biosynthesis ${ }^{65}$. It is clear that the sub-cellular enzyme work begun in the Oxford laboratory of EDWARD P. ABRAHAM provided the breakthrough needed by the field for elucidation of the pathways leading to fungal penicillins and cephalosporins. It also opened the way for our understanding of the production of cephamycins, clavams and other $\beta$-lactams by the actinomycetes and other bacteria. The isolation of the pure enzymes, determination of their crystal structures ${ }^{66)}$, discovery of the genes involved ${ }^{67)}$ and their chromosomal locations, elucidation of the regulation of the genes and enzymes ${ }^{68.69)}$, cloning and expression of the genes in heterologous hosts ${ }^{70)}$ and consideration of the evolutionary relationships ${ }^{71)}$ all followed on the heels of the development of reliable cell-free systems. I will always be indebted to the late EDWARD P. ABRAHAM for his scholarship, his highly ethical character and his generous offers to help a young industrial microbiologist contribute to the world of technology and science.

\section{References}

1) Stevens, C. M.; P. Vohra \& C. W. de Long: Utlilization of valine in the biosynthesis of penicillins. J. Biol. Chem. 211: $297 \sim 300,1954$

2) Arnstein, H. R. V. \& P. T. Grant: The biosynthesis of penicillin. The incorporation of some amino acids into penicillin. Biochem. J. 57: 360 368, 1954

3) Gordon, M.; S. C. Pan, A. Virgona \& P. Numerof: Biosynthesis of penicillin. I. Role of phenylacetic acid. Science 118: 43, 1953 
4) Demain, A. L.: Inhibition of penicillin formation by amino acid analogs. Arch. Biochem. Biophys. 64: 74 79, 1956

5) Demain, A. L.: Inhibition of penicillin formation by lysine. Arch. Biochem. Biophys. 67: 244 246, 1957

6) Bonner, D.: Studies on the biosynthesis of penicillin. Arch. Biochem. 13: 1 9, 1947

7) Kato, K.: Occurrence of penicillin-nucleus in culture broths. J. Antibiotics. Ser. A 6: 184 185, 1953

8) Demain, A. L.: The mechanism of penicillin biosynthesis. Adv. App. Microbiol. 1: 23 45, 1959

9) Batchelor, F. R.; F. P. Doyle, J. H. C. Nayler \& G. N. RoLInSON: Synthesis of penicillin: 6-amino-penicillanic acid in penicillin fermentations. Nature 183: 257 258, 1959

10) Somerson, N. L.; A. L. Demain \& T. D. Nunheimer: Reversal of lysine inhibition of penicillin production by $\alpha$-aminoadipic or adipic acid. Arch. Biochem. Biophys. 93: $238 \sim 241,1961$

11) Arnstein, H. R. V. \& D. Morris: The structure of a peptide, containing $\alpha$-aminoadipic acid, cysteine, and valine, present in the mycelium of Penicillium chrysogenum. Biochem. J. 76: 357 361, 1960

12) Flynn, E. II; M. H. MCCormik, M. C. Stamper, H. VAlERIA \& C. W. GodzeskI: A new natural penicillin from Penicillium chrysogenum. J. Amer. Chem. Soc. 84: 4594 4595, 1962

13) Demain, A. L.: Biosynthesis of penicillins and cephalosporins. In Biosynthesis of Antiobiotics. Vol. 1. Ed., J. Snell, pp. 37 53, Academic Press, NY, 1967

14) Masurekar, P. S. \& A. L. Demain: Lysine control of penicillin biosynthesis. Can. J. Microbiol. 18: $1045 \sim 1048,1972$

15) Demain, A. L. \& P. S. Masurekar: Lysine inhibition of in vivo homocitrate synthesis in Penicillium chrysogenum. J. Gen. Microbiol. 82: 143 151, 1974

16) Masurekar, P. S. \& A. L. Demain: Impaired penicillin production in lysine regulatory mutants of Penicillium chrysogenum. Antimicrob. Agents Chemother. 6: 366 368, 1974

17) Masurekar, P. S. \& A. L. Demain: Insensitivity of homocitrate synthase in extracts of Penicillium chrysogenum to feedback inhibition by lysine. Appl. Microbiol. 28: 265 270, 1974

18) Friedrich, C. G. \& A. L. Demain: Homocitrate synthase as the crucial site of the lysine effect on penicillin biosynthesis. J. Antibiotics 30: 760 761, 1977

19) Friedrich, C. G. \& A. L. Demain: Uptake and metabolism of $\alpha$-aminoadipic acid by Penicillium chrysogenum. Wis 54-1255. Arch. Microbiol. 119: $43 \sim 47,1978$

20) Gottshall, R. Y.; J. M. Roberts, L. M. Portwood \& J. C. JENNINGS: Synnematin, an antibiotic produced by Tilachlidium. Proc. Soc. Exp. Biol., N. Y. 76: 307 -311, 1951

21) Crawford, K.; N. G. Heatley, P. F. Boyd, C. W. Hale, B. K. Kelly, G. A. Miller \& N. Smith: Antibiotic production by a species of Cephalosporium. J. Gen. Microbiol. 6: 47 59, 1952

22) Abraham, E. P.; G. G. F. Newton, J. R. Schenck, M. P. Hargie, B. H. Olson, D. M. Schuurmans, M. W. Fisher \& S. A. FusARI: Identity of cephalosporin $\mathrm{N}$ and synnematin B. Nature 176: 551, 1955
23) Newton, G. G. F. \& E. P. Abraham: Cephalosporin C, a new antibiotic containing sulphur and $\mathrm{D}$ - $\alpha$-amino-adipic acid. Nature 175: 548, 1955

24) Abraham, E. P. \& G. G. F. Newton: The structure of cephalosporin C. Biochem. J. 79: 337 393, 1961

25) ABraham, E. P.: Biochemistry of some peptide and steroid antibiotics. John Wiley \& Sons, Inc., N.Y. 1957

26) Trown, P. W. E. P. Abraham, G. G. F. Newton, C. W. Hale \& G. A. Miller: Incorporation of acetate into cephalosporin C. Biochem. J. 84: 157 166, 1962

27) Trown, P. W; M. Sharp \& E. P. Abraham: $\alpha$ Oxoglutarate as a precursor of the $\mathrm{D}$ - $\alpha$-aminoadipic residue in cephalosporin C. Biochém. J. 86: 280 -284, 1963

28) ABraham, E. P.: Penicillins and cephalosporins. Symposium on Antibiotics, St. Marguerite, Quebec, Canada, pp. 399 412, 1971

29) Loder, P. B. \& E. P. Abraham: Isolation and nature of intracellular peptides from a cephalosporin C-producing Cephalosporium sp. Biochem. J. 123: 471 476, 1971

30) Loder, P. B. \& E. P. Abraham: Biosynthesis of peptides containing $\alpha$-aminoadipic acid and cysteine in extracts of a Cephalosporium sp. Biochem. J. 123: 477 482, 1971

31) ABraham, E. P.: Biosynthesis and enzymic hydrolysis of penicillins and cephalosporins. University of Tokyo Press, Tokyo, 1974

32) Fawcett, P. A.; J. J. Usher \& E. P. Abraham: Aspects of cephalosporin and penicillin biosynthesis. 2nd Int. Symp. Gen. Industr. Microorgs. pp. 129 138, Academic Press, New York, 1976

33) Abraham, E. P.; G. G. F. Newton \& S. C. Warren: In Biogenesis of Antibiotic Substances. Eds., VANEK, Z. \& Z. HostaleK, pp. 169 194, Czechoslovak Academy of Sciences, Prague, 1965

34) Duncan, M. \& G. G. F. Newton: Preparation and some properties of protoplasts from Cephalosporium sp. Proc. 2nd Internat. Symp. on Yeast Protoplasts, Brno, Aug. 20 23, 1968. Acta Fac. Med. Univ. Brun. 37: 129 136, 1970

35) Bost, P. E. \& A. L. Demain: Studies on the cell-free biosynthesis of $\beta$-lactam antibiotics. Biochem. J. 162: $681 \sim 687,1977$

36) Kohsaka, M. \& A. L. Demain: Conversion of penicillin $\mathrm{N}$ to cephalosporin $\mathrm{C}$ by cell-free extracts of Cephalosporium acremonium. Biochem. Biophys. Res. Comm. 70: 465 473, 1976

37) Yoshida, M.; T. Konomi, M. Kohsaka, J. E. Baldwin, S. Herchen, P. Singh, N. A. Hunt \& A. L. Demain: Cellfree ring expansion of penicillin $\mathrm{N}$ to deacetoxycephalosporin $\mathrm{C}$ by Cephalsoporium acremonium CW19 and its mutants. Proc. Natl. Acad. Sci. U.S.A. 75: $6253 \sim 6257,1978$

38) Fawcett, P. A.; P. B. Loder, M. J. Duncan, T. J. BEESLEY \& E. P. ABRAhaM: Formation and properties of protoplasts from antibiotic-producing strains of Penicillium chrysogenum and Cephalosporium acremonium. J. Gen. Microbiol. 79: 293 309, 1973

39) O'Sullivan, J. R.; C. Bleaney, J. A. Huddleston \& E. P. ABRAHAM: Incorporation of ${ }^{3} \mathrm{H}$ from $\delta$ - $(\mathrm{L}-\alpha-$ amino- $[4,5-3 H]$ adipyl-L-cysteinyl-D- $\left[4,4-{ }^{3} \mathrm{H}\right]$ valine into isopenicillin N. Biochem. J. 184: 421 426, 1979

40) Konomi, T.; S. Herchen, J. E. Baldwin, M. Yoshida, N. 
A. Hunt \& A. L. Demain: Cell-free conversion of $\delta$-(L$\alpha$-aminoadipyl)-L-cysteinyl-D-valine into an antibiotic with the properties of isopenicillin $\mathrm{N}$ in Cephalosporium acremonium. Biochem. J. 184: 427 430, 1979

41) Demain, A. L.; J. KupKa, Y. Q. Shen \& S. Wolfe: Microbiological synthesis of $\beta$-lactam antibiotics. In Trends in Antibiotic Research. Eds., UmezawA, H., A. L. Demain, T. Hata \& C. R. Hutchinson. pp. $233 \sim 247$, Japan Antibiotic Research Assocaition, Tokyo, 1982

42) Abraham, E. P.: $\beta$-Lactam antibiotics and related substances. Jpn. J. Antibiotics 30: S1 S25, 1977

43) Fawcett, P. A.; J. J. Usher \& E. P. Abraham: Behavior of tritium-labelled isopenicillin $\mathrm{N}$ and 6aminopenicillanic acid as potential penicillin precursors in an extract of Penicillium chrysogenum. Biochem. J. 151: $741 \sim 746,1975$

44) Hook, D. J.; L. T. Chang, R. P. Elander \& R. B. MorIN: Stimulation of the conversion of penicillin $\mathrm{N}$ to cephalosporin by ascorbic acid, $\alpha$-ketoglutarate, and ferrous ions in cell-free extracts of strains of Cephalosporium acremonium. Biochem. Biophys. Res. Commun. 87: 258 265, 1979

45) Sawada, Y.; N. A. Hunt \& A. L. Demain: Further studies on microbiological ring-expansion of penicillin N. J. Antibiotics 32: 1303 1310, 1979

46) Kupka, J.; Y. Q. Shen, S. Wolfe \& A. L. Demain: Studies on the ring-cyclization and ring-expansion enzymes of $\beta$-lactam biosynthesis in Cephalosporium acremonium. Can. J. Microbiol. 29: 488 496, 1983

47) Felix, H. R.; H. H. Peter \& H. J. Treichler: Microbiological ring expansion of penicillin N. J. Antibiotics 34: 567 -575, 1981

48) Sawada, Y.; J. E. Baldwin, P. D. Singh, N. A. Solomon $\&$ A. L. Demain: Cell-free cyclization of $\delta$-(L- $\alpha-$ aminoadipyl)-L-cysteinyl-D-valine to isopenicillin $\mathrm{N}$. Antimicrob. Agents Chemother. 18: 465 470, 1980

49) Jayatilake, G. S.; J. A. Huddleston \& E. P. Abraham: Conversion of isopenicillin $\mathrm{N}$ into penicillin $\mathrm{N}$ in cellfree extracts of Cephalosporium acremonium. Biochem. J. 194: 645 647, 1981

50) Baldwin, J. E.; E. P. Keeping, P. D. Singh \& C. A. VALLEJO: Cell-free conversion of isopenicillin $\mathrm{N}$ into deacetoxycephalosporin $\mathrm{C}$ by Cephalosporium acremonium mutant M-0198. Biochem. J. 194: $649 \sim 651,1981$

51) Demain, A. L.: Biosynthetic manipulations in the development of $\beta$-lactam antibiotics. In $\beta$-Lactam Antibiotics: Mode of Action, New Developments and Future Prospects. Eds., Salton, M. R. J. \& G. D. Shockman, pp. 567 583, Academic Press, N.Y., 1981

52) Liersch, M.; J. Nuesch \& H. J. Treichler: Final steps in the biosynthesis of cephalosporin C. In Second International Symposium on the Genetics of Industrial Microorganisms. Ed., K. D. MaCDONALD, pp. 179 195, Academic Press, New York, 1976

53) FunisaWA, Y. \& T. KanAZAKI: Role of acetyl CoA: Deacetylcephalosporin C Acetyltransferase in cephalosporin $\mathrm{C}$ biosynthesis by Cephalosporium acremonium. Agric. Biol. Chem. 39: 2043 2048, 1975

54) Brewer, S. J.; J. E. Farthong \& M. K. Turner: The oxygenation of the 3 -methyl group of 7- $\beta(5-\mathrm{D}-$ aminoadipamido)-3-methylceph-3-em-4-carboxylic acid (desacetoxycephalosporin $\mathrm{C}$ ) by homogenates of
Acremonium chrysogenum. Biochem. Soc. Trans. 5: $1024 \sim 1025,1977$

55) FuJisaWA, Y.; M. KIKUCHI \& T. KANZAKI: Deacetylcephalosproin $\mathrm{C}$ synthesis by cell-free extracts of Cephalosporium acremonium. J. Antibiotics 30: 775 777, 1977

56) Hollander, I. J.; Y. Q. Shen, J. Heim, A. L. Demain \& S. WOLFE: A pure enzyme catalyzing penicillin biosynthesis. Science 224: $610 \sim 612,1984$

57) Baldwin, J. E.; J. Gagnon \& H. H. Ting: N-terminal amino-acid sequence and some properties of isopenicillin $\mathrm{N}$ synthetase from Cephalosporium acremonium. FEBS Lett. 188: 253 256, 1985

58) Dotzlaf, J. E. \& W. K. YeH: Copurification and characterization of deacetoxycephalosporin C synthetase/hydroxylase from Cephalosporium acremonium. J. Bacteriol. 169: 1611 1618, 1987

59) Usul, S. \& C. Y. YU: Purification and properties of isopenicillin $\mathrm{N}$ epimerase from Streptomyces clavuligerus. Biochim. Biophys. Acta 999: 78 85, 1989

60) Banko, G.; S. Wolfe \& A. L. Demain: Cell-free synthesis of $\delta$-(L- $\alpha$-aminoadipyl)-L-cysteine, the first intermediate of penicillin and cephalosporin biosynthesis. Biochem. Biophys. Res. Commun. 137: 528 535, 1986

61) Banko, G.; A. L. Demain \& S. Wolfe: $\delta$-(L- $\alpha-$ Aminoadipyl)-L-cysteinyl-D-valine synthetase (ACV synthetase): A multifunctional enzyme with broad substrate specificity for the synthesis of penicillin and cephalosporin precursors. J. Amer. Chem. Soc. 109: 2858 2860, 1987

62) Zhang, J. \& A. L. Demain: Purification from Cephalosporium acremonium of the initial enzyme unique to the biosynthesis of penicillins and cephalosporins. Biochem. Biophys. Res. Comm. 169: $1145 \sim 1152,1990$

63) Zhang, J. \& A. L. Demarn: ACV Synthetase. Crit. Rev. Biotechnol. 12: 245 260, 1992

64) Aharonowitz, Y; J. Bergmeyer, J. M. Cantoral, G. Cohen, A. L. Demain, U. Fink, J. Kinghorn, H. Kleinkauf, A. MacCabe, H. Palissa, E. Pfeifer, T. SCHWECKe, H. VAN Liempt, H. von Dohren, S. Wolfe \& J. ZHANG: $\delta$-(L- $\alpha$-Aminoadipyl)-L-cysteinyl-D-valine synthetase, the multienzyme integrating the four primary reactions in $\beta$-lactam biosynthesis, as a model peptide synthetase. Bio/Technology 11: 807 810, 1993

65) Martin, J. F.; Gutierrez \& A. L. Demain: $\beta$-Lactams. In Fungal Biotechnology. Ed., T. ANKE, pp. 91 127, Chapman \& Hall, Weinheim, Germany, 1997

66) Valegard, K.; A. C. T. van Schelinga, M. D. Lloyd, T. Hara, S. Ramaswamy, A. Perrakis, A. Thompson, H. J. Lee, J. E. Baldwin, C. J. Schofield, J. Hajdu \& I. ANDERSSON: Structure of a cephalosporin synthase. Nature 394: 805 809, 1998

67) Martin, J. F.: New aspects of genes and enzymes for $\beta$-lactam antibiotic biosynthesis. Appl. Microbiol. Biotechnol. 50: 1 15, 1998

68) BraKhage, A. A.: Molecular regulation of $\beta$-lactam biosynthesis in filamentous fungi. Microbiol. Mol. Biol. Rev. 62: 547 585, 1998

69) Demain, A. L. \& J. Zhang: Cephalosporin C production by Cephalosporium acremonium: the methionine story. Crit. Rev. Biotechnol. 18: 283 294, 1998 
70) Carr, L. G.; P. L. Skatrud, M. E. Scheetz, S. W. QUEENER \& T. D. Ingolia: Cloning and expression of the isopenicillin $\mathrm{N}$ synthetase gene from Penicillium chrysogenum. Gene 48: 257 266, 1986
71) Aharonowitz, Y. G.; Cohen \& J. F. Martin: Penicillin and cephalosporin biosynthetic genes: structure, organization, regulation, and evolution. Ann. Rev. Microbiol. 46: 461 495, 1992 